Gut, 1988, 29, 848-851

Case report

\title{
Bleeding from multifocal heterotopic gastric mucosa in the colon controlled by an $\mathrm{H}_{2}$ antagonist
}

\author{
F E MURRAY, M LOMBARD, P DERVAN, R J FITZGERALD, \\ AND J CROWE \\ From the Departments of Gastroenterology and Pathology, Mater Misericordiae Hospital, Dublin, and \\ Department of Surgery, Our Lady's Hospital for Sick Children, Crumlin, Dublin, and University College, \\ Dublin, Ireland
}

\begin{abstract}
SUMMARY The sixth documented case of heterotopic gastric mucosa in the large bowel proximal to the rectum is described in a two year old girl with a neural tube defect and recurrent rectal bleeding. Unusual in itself, this case is unique in that the rectal bleeding has been controlled with an $\mathrm{H}_{2}$ receptor antagonist.
\end{abstract}

Heterotopic gastric mucosa involving the hindgut is exceedingly rare, especially at sites other than the rectum. The management of all cases described to date has involved surgical excision of the affected bowel. A new approach to management is presented in this case report.

\section{Case history}

After an uncomplicated pregnancy, this young girl was born at full term, weight $4.5 \mathrm{~kg}$, with a $3 \times 3 \mathrm{~cm}$ lumbar myelomeningocoele containing a small neural stalk. This was successfully repaired and moderate hydrocephalus controlled with oral isosorbide dinitrate.

An anteriorly placed anus functioned well until six months of age, when bleeding per rectum and constipation developed. An anoplasty was carried out followed by regular dilatation.

At one month, two months, four months, and 16 months rectal bleeding recurred. Haemoglobin was $5.4 \mathrm{~g} / \mathrm{dl}$. Barium meal and follow through, barium enema, coagulation screen and repeated stool examination for ova, parasites, culture and sensitivity were normal and negative respectively. Technetium scan revealed increased isotope uptake in the right iliac fossa suggestive of Meckel's diverticulum (Fig. 1).

Address for correspondence: Dr J Crowe. Dept of Gastroenterology, Mater Misericordiac Hospital, Dublin, Ireland.

Received for publication 12 January 1988
Laparotomy revealed a $1 \mathrm{~cm}$ Meckel's diverticulum, lined with normal small bowel mucosa which was removed. In addition, an ulcer with surrounding induration was excised from the proximal ascending colon with histology revealing a localised ulcer in inflamed colonic mucosa.

Colonoscopy revealed a polypoid oedematous lesion in the rectum, prominent hyperaemic fold in the sigmoid region, and ulcerated swollen mucosa in the ascending colon and caecum. Biopsy of each of these lesions revealed heterotopic body type gastric mucosa (Fig. 2). Oral ranitidine $15 \mathrm{mg}$ bd was started which initially controlled the bleeding. Repeat colonoscopy, four months later, showed a reduction in the size of the lesion and healing of the ulcerated areas. After a small episode of bleeding five months after initiation of therapy, the dose of ranitidine was increased to $30 \mathrm{mg}$ bd $(4 \mathrm{mg} / \mathrm{kg} / \mathrm{day})$. No further bleeding has recurred. This standard dose of ranitidine has fully controlled the bleeding to date.

\section{Discussion}

In this case report, a young girl is described with repeated episodes of rectal bleeding because of heterotopic gastric mucosa present in the rectum, sigmoid colon, ascending colon, and caecum. The widespread distribution of the lesions made conservative surgery difficult. The patient was treated successfully with an $\mathrm{H}_{2}$ receptor antagonist, raniti- 


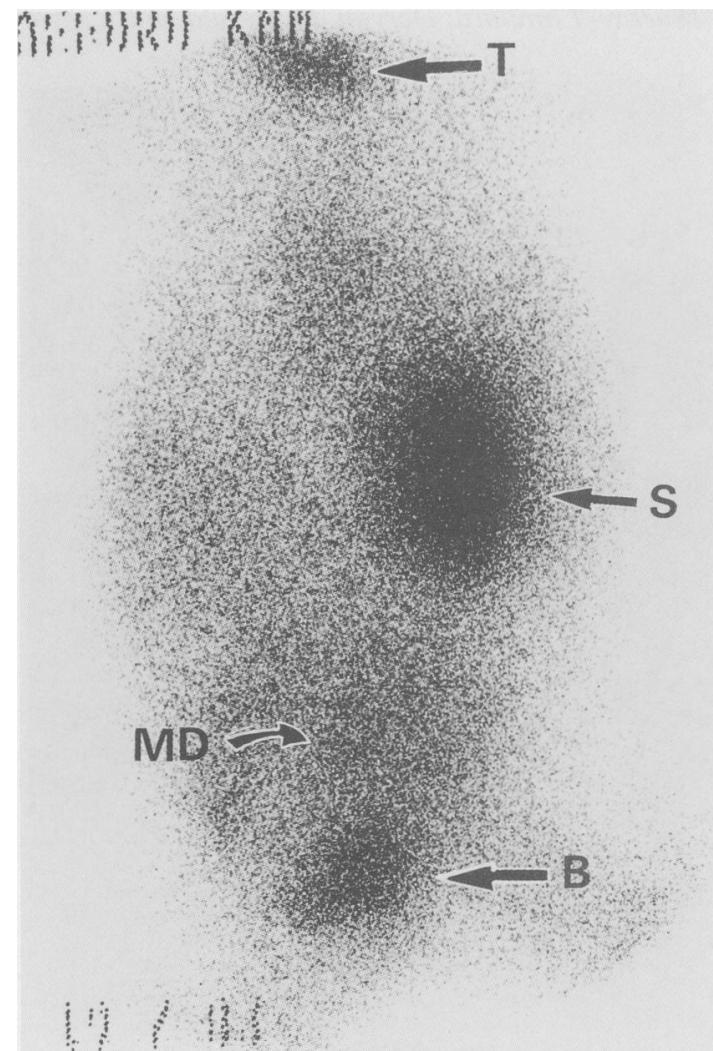

Fig. 1 Technetium scan showing increased uptake of radioisotope in the right lower abdomen suggestive of Meckel's diverticulum (MD). Also shown: thyroid (T), stomach $(S)$, and urinary bladder $(B)$.

Table 1a Summary of reported cases of heterotopic gastric mucosa in rectum

\begin{tabular}{|c|c|c|c|c|c|c|}
\hline Age/sex & Presenting symptom & $\begin{array}{l}\text { Duration of } \\
\text { symptoms }\end{array}$ & $\begin{array}{l}\text { Sigmoidoscopic } \\
\text { findings }\end{array}$ & Type of mucosa & Associated anomalies & Reference \\
\hline $4 / \mathrm{F}$ & Rectal bleeding & 2 yrs & Rectal diverticulum & Fundic & Rectal duplication & 15 \\
\hline $45 / \mathrm{M}$ & Rectal bleeding & 4 yrs & Polypoidal tumour & Fundic + pyloric & None & 16 \\
\hline $26 / F$ & Rectal bleeding + tenesmus & 16 yrs & Polypoidal tumour & Fundic & None & 17 \\
\hline $26 / \mathrm{M}$ & Rectalblecding & 2 yrs & Polypoidal tumour & Fundic & $\begin{array}{l}\text { Rectal diverticulum } \\
\text { Meckels diverticulum } \\
\text { Colonic rotation } \\
\text { Vertebral defects }\end{array}$ & 18 \\
\hline $19 / \mathrm{F}^{*}$ & Rectal bleeding + diarrhoca & 7 days & Multifocal ulcers & Fundic + pyloric & $\begin{array}{l}\text { Malrotation } \\
\text { Vertebral anomalies } \\
\text { Megacolon }\end{array}$ & 19 \\
\hline $7 / \mathbf{M}$ & Rectalbleeding & - & Polypoidal tumour & Fundic & None & 20 \\
\hline $51 / \mathbf{M}$ & Rectal bleeding/ulceration & $3 \mathrm{mo}$ & Ulcer & Pyloric & None & 20 \\
\hline $46 / F$ & Rectal Mass & $21 / 2 \mathrm{mo}$ & Polyp & Fundic & None & 20 \\
\hline $24 / \mathrm{M}$ & Rectal bleeding + pain & 3 yrs & Normal & Fundic + salivary & $\begin{array}{l}\text { Rectal diverticulum } \\
\text { Vertebral anomalies }\end{array}$ & 21 \\
\hline 14/M & Rectal bleeding & $12 \mathrm{yrs}$ & Ulceration & Gastric & None & 22 \\
\hline $24 / \mathrm{M}$ & Rectal bleeding & Not stated & Polypoidal tumour & Fundic & None & 23 \\
\hline $22 / \mathrm{M}$ & Rectal bleeding + tenesmus & 6 days & Polypoidal tumour & Fundic & None & 24 \\
\hline $6 \mathrm{mo} / \mathrm{M}$ & Rectalblecding & $4 \mathrm{mo}$ & Polypoidal tumour & Fundic & None & 25 \\
\hline 4/M & Rectal bleeding & $1 \mathrm{yr}$ & Ulcer & Fundic & Rectal duplication & 26 \\
\hline $16 / \mathrm{M}$ & Rectal bleeding + pain & $5 \mathrm{yrs}$ & Polypoidal tumour & Fundic & None & 27 \\
\hline
\end{tabular}

dine, in an effort to reduce acid secretion and thus reduce ulceration and bleeding. This is the first described case of medical therapy controlling haemorrhage from heterotopic gastric mucosa, and suggests that the mechanism controlling secretion by heterotopic mucosa may be similar to that operating in normal gastric mucosa.

Heterotopic gastric mucosa has been reported all along the alimentary tract, including tongue, oesophagus, ${ }^{1-3}$ small intestine, ${ }^{+7}$ biliary tract, ${ }^{,-9}$ gall bladder, ${ }^{11}$ colon and rectum, ${ }^{15-31}$ the most common being in Meckel's diverticulum. In addition, heterotopic gastric mucosa has been described in the mediastinum, ${ }^{11}$ face, ${ }^{12}$ spinal cord,${ }^{13}$ and umbilicus. ${ }^{14}$

Gastric heterotopia in segments of the alimentary tract derived from the fetal hindgut is extremely rare. Review of the literature has revealed 10 cases involving the rectum alone (Table 1a), four having an associated reduplication of the rectum; and only five cases involving the colon proximal to the rectum (one of whom also had rectal involvement and is included in Table 1a) - Table 1b. ${ }^{15-31}$

Five of these 19 reported cases have had anomalies of other systems: vertebral (four), digital (one), and other heterotopias. All cases, except one ${ }^{20}$ have shown fundic type gastric mucosa. Only six previous cases have been reported in children.

The majority of cases presenting with gastric heterotopia involving the rectum present with rectal bleeding (Table 1a), and a mass or rectal ulceration may be seen on sigmoidoscopy.

*Also had proximal colonic involvement (see Table lb) 


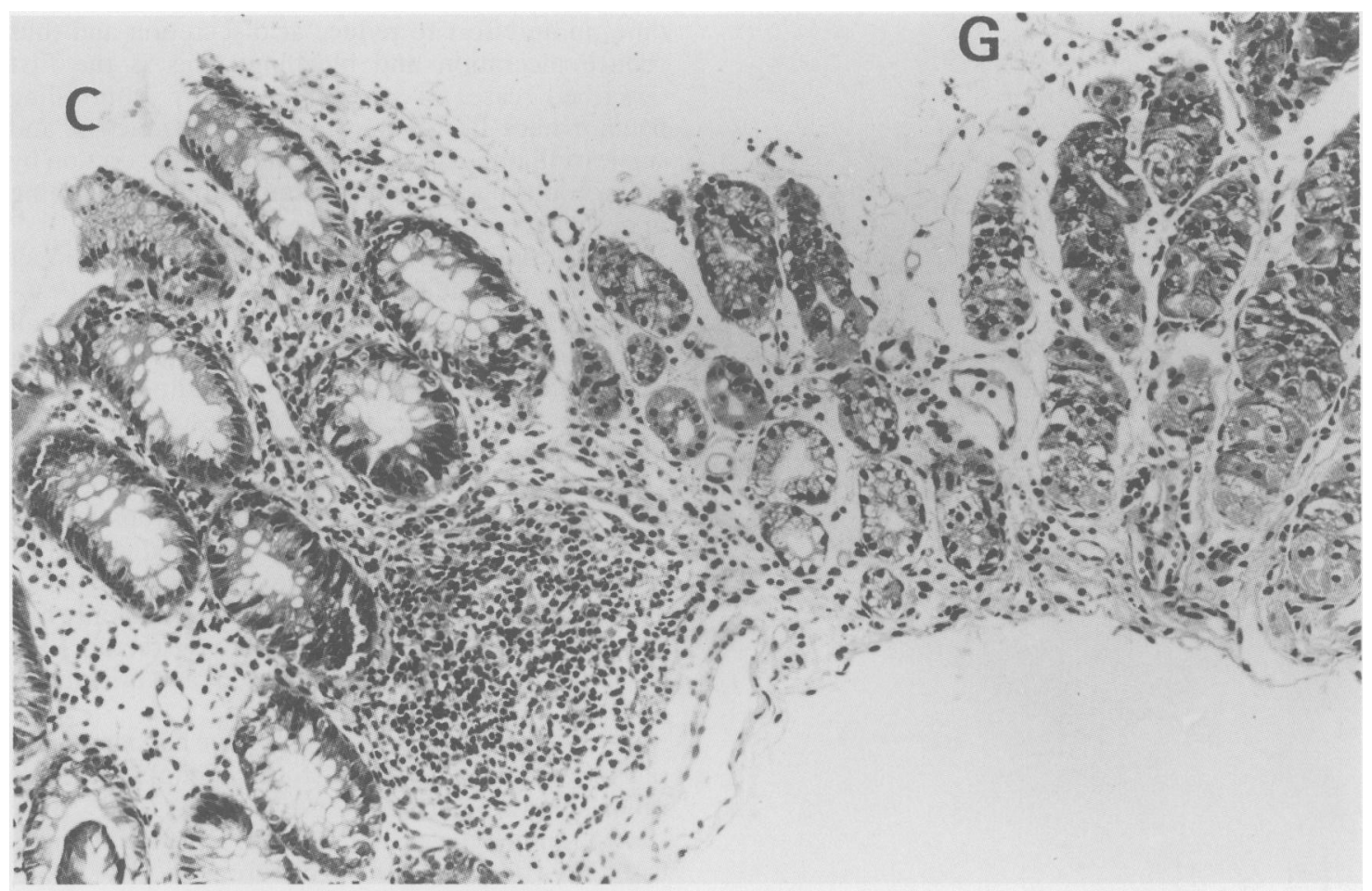

Fig. 2 Heterotopic gastric body type mucosa $(G)$ adjacent to normal colonic mucosa $(C)$. $H \& E$.

In contrast, in those patients with lesions proximal to the rectum, the clinical presentation is more varied with diarrhoea (two cases), rectal bleeding (one case), acute appendicitis (one case), and intussusception (one case). Rectal bleeding is less prominent in this group. There has only been one previous case report describing both proximal and distal large bowel involvement,$^{19}$ it is noteworthy that this patient also had spina bifida.

The aetiology of colonic heterotopia is uncertain. Although gastric heterotopia in foregut structures may be caused by dislocations of part of the embryonic structures during developmental descent of the stomach, such an explanation is not tenable in the hindgut. It has been suggested that it may arise as a result of abnormal differentiation of local tissues (heteroplasia) based on the concept that all the cells lining the primitive intestinal canal are pluripotential. ${ }^{32}$

It has also been suggested that the condition may be acquired, and represents an abnormal regenerative process after mucosal destruction. ${ }^{33 \cdot} \mathrm{A}$ develop-

Table 1b Summary of reported cases of heterotopic gastric mucosa in the colon, proximal to the rectum

\begin{tabular}{|c|c|c|c|c|c|c|}
\hline Age/sex & Presenting features & $\begin{array}{l}\text { Duration of } \\
\text { symptoms }\end{array}$ & $\begin{array}{l}\text { Segment of colon } \\
\text { involved }\end{array}$ & $\begin{array}{l}\text { Type of heterotopic } \\
\text { tissue }\end{array}$ & Associated anomalies & Reference \\
\hline $4 / \mathrm{F}$ & Colocolic intussuception & Not stated & Transverse & $\begin{array}{l}\text { Gastric duodènal } \\
\text { appendiceal } \\
\text { pancreatic }\end{array}$ & None & 28 \\
\hline $19 / \mathrm{F}$ & Not stated & Not stated & Ascending & Gastric & None & 29 \\
\hline $0 / \mathbf{M}$ & Watery diarrhoca & From birth & $\begin{array}{l}\text { Caecum, ascending } \\
\text { colon }\end{array}$ & $\begin{array}{l}\text { Gastrict } \\
\text { ocsophageal }\end{array}$ & Rib+vertebrac & 30 \\
\hline $14 / M$ & Acute appendicitis & 1 day & Appendix & Gastric & None & 31 \\
\hline $19 / \mathrm{F}^{*}$ & Diarrhoca rectal bleeding & 7 days & $\begin{array}{l}\text { Ascending transverse } \\
\text { descending colon }\end{array}$ & Fundic + pyloric & $\begin{array}{l}\text { Spina bifida occulta } \\
\text { Malrotation } \\
\text { Megacolon }\end{array}$ & 19 \\
\hline
\end{tabular}

${ }^{*}$ Also had rectal involvement (see Table la) 
mental aetiology appears the more likely in view of the association with neural tube and other abnormalities.

All the previous cases described have been managed by surgical excision of the affected area. Because of the widespread colonic extent of the abnormality in this case, medical therapy using an $\mathrm{H}_{2}$ receptor antagonist was first attempted. This has resulted in immediate and adequate control of haemorrhage (with one small episode of breakthrough bleeding), and healing of ulceration and decrease in size of the lesions noted at colonoscopy, allowing the child to continue without colonic resection. The mechanism of action of ranitidine in this case is open to debate. The rationale behind its use was that the heterotopic gastric mucosa, like that in the stomach, has $\mathrm{H}_{2}$ receptors responsible for control of acid output, which could be blocked by appropriate drug therapy, decreasing acid secretion and thus colonic ulceration and bleeding. The success of this therapy suggests that this may well be the case.

We wish to thank Miss June Fogarty for secretarial assistance.

\section{References}

1 Rector LE, Connerley ML. Aberrant mucosa in the oesophagus in infants and children. Arch Pathol 1941; 31: 285-94.

2 Taylor AL. The epithelial heterotopias of the alimentary tract. J Pathol Bacteriol 1944; 30: 375-80.

3 De La Pava S, Pickren JW, Alder RH. Ectopic gastric mucosa of the oesophagus: A study of histogenesis. New York J Med 1964; 64: 1831-5.

4 Frazin G, Musola R, Negri A, Mencarelli R, Fratton A. Heterotopic gastric (fundic) mucosa in the duodenum. Endoscopy 1982; 14: 166-7.

5 Loo SM, Mosenthal MT, Weismann RE. Tumourous heterotopic gastric mucosa in the small intestine. Arch Surg 1970; 100: 619-22.

6 Vizcarrondo FJ, Wang TY, Brady PG. Heterotopic gastric mucosa: presentation as a rugose duodenal mass. Gastrointest Endosc 1983; 29: 107-10.

7 Newmark H, Ching G, Halls J, Levy IJ. Bleeding peptic ulcer caused by ectopic gastric mucosa in a duplicated segment of jejunum. Am J Gastroenterol 1981; 75: $158-62$.

8 Blundell CR, Kanum CS, Earnest DL. Biliary obstruction by heterotopic gastric mucosa at the ampulla of Vater. Am J Gastroenterol 1982; 77: 111-4.

9 Kalman PG, Stone RM, Phillips MJ. Heterotopic gastric mucosa of the bile duct. Surgery 1981; 89: 384-6.

10 Mooney B, O’Malley E, Dempsey J. Gastric heterotopia in a gall bladder. Irish J Med Sci 1979; 148: 50-3.

11 Willis RA. Some unusual developmental heterotopias. Br Med J 1968; iii: 267.

12 Wolf M, Ranhew RM. Heterotopic gastric epithelium in the head and neck region. Ann Plast Surg 1980; 4: 53-64.

13 Knight G, Griffiths T, William I. Gastrocystoma of the spinal cord. Br J Surg 1955; 42: 635-8.

14 Nicholson GW. Gastric gland in the extroverted distal end of the vitteline duct. J Pathol Bacteriol 1922; 25: 201-6.

15 Stockman JM, Young VT, Jenkins AL. Duplication of the rectum containing gastric mucosa. JAMA 1960; 173: 1123-5.

16 Goldfarb WB, Schaefer R. Gastric heterotopia in the rectum: report of a case. Ann Surg 1961; 154: 133-6.

17 Cox RW. A case of gastric heterotopia in the rectum. $J$ Pathol Bacteriol 1962; 84: 427-8.

18 Manz DJ, Kenaeter JP, Waltz PK. Rectal duplication lined by gastric mucosa in an adult. Am J Surg 1964; 107: 887-90.

19 Dubelier LD, Caffrey PR, Hyde DL. Multifocal gastric heterotopia in a malformation of the colon presenting as a megacolon. Am J Clin Pathol 1969; 51: 646-53.

20 Wolff $M$. Heterotopic gastric epithelium in the rectum: a report of 3 new cases with a review of 87 cases of heterotopia in alimentary canal. Am J Clin Pathol 1971; 55: 604-16.

21 Shindo K, Bacon HE, Holmes EJ. Ectopic gastric mucosa and glandular tissue of a salivary type in the anal canal concomitant with a diverticulum of haemorrhoidal tissue. Report of a case. Dis Colon Rect 1972; 15: 57-62.

22 Picard EJ, Picard JJ, Jorissen J, et al. Heterotopic gastric mucosa in the epiglottis and rectum. Am J Dig Dis 1978; 23: $217-21$.

23 Shimer GP. Case for diagnosis: Heterotopic gastric mucosa of the rectum. Milit Med 1980; 145: 771-2.

24 Debas HT, Chaun H, Thomson FB, Sion Shiona P. Functioning heterotopic oxyntic mucosa in the rectum. Gastroenterology 1980; 79: 1300-2.

25 Schwartzenberg SJ, Whitington PF. Rectal gastric mucosa heterotopia as a cause of hematochezia in an infant. Dig Dis Sci 1983; 28: 470-3.

26 Kalani BP, Vaezzadeh K, Sieber WK. Gastric heterotopia of rectum complicated by rectovesical fistula. Dig Dis Sci 1983; 28: 378-80.

27 Jordon FT, Mazzeo RJ, Soiderer MH. Heterotopic gastric mucosa of the rectum. Arch Surg 1983; 118: 878-90.

28 Burne JC. Pancreatic and gastric heterotopia in a diverticulum of transverse colon. $J$ Pathol Bacteriol 1958; 75: 470-1.

29 Nicholson GW. Heteromorphoses (Metaplasia) of alimentary tract. J Pathol Bacteriol 1923; 26: 399-417.

30 Aterman K, Abaci F. Heterotopic gastric and oesophageal tissue in the colon. Am J Dis Childh 1967; 113: 552-9.

31 Droga BW, Levine S, Baber JJ. Heterotopic gastric and oesophageal tissue in the vermiform appendix. Am J Clin Pathol 1963; 40: 190-3.

32 Morrison JE. Foetal and neonatal pathology. Washington DC: Butterworth, 1963: 297-8.

33 Ming SC, Simon M, Tandon B. Gross gastric metaplasia of ileum after regional enteritis. Gastroenterology 1962; 44: $63-8$. 